\title{
Identifikasi Senyawa Bahan Alam Sebagai Inhbitor Tirosin Kinase EGFR: Skrining In Silico Berbasis Farmakofor Dan Molecular Docking
}

\author{
Frangky Sangande $^{1 *}$, Jonly Piere Uneputty ${ }^{1}$ \\ ${ }^{1}$ Program Studi Farmasi, Fakultas Sains dan Teknologi, Universitas Prisma Manado
}

\begin{tabular}{l}
\hline \multicolumn{1}{c}{ Article info } \\
\hline History \\
Submission: 07-09-2019 \\
Review: $19-10-2020$ \\
Accepted: $19-01-2021$ \\
"Email: \\
frangky.sangande@ prisma.ac.id
\end{tabular}

DOI: $10.33096 /$ jffi.v8i1.539

Keywords:

EGFR, in silico, pharmacophore modeling, molecular docking

\begin{abstract}
Epidermal growth factor receptor (EGFR) is one of tyrosine kinase that overexpressed in many types of cancer. The ihbiition of EGFR activity has known as a rational target for cancer therapy. However, several EGFR inhibitors have limitations related to resistance problems or reduced tumor response. Therefore, the effort to develop new inhibitors with greater efficacy is very important to overcome the problems. In the present study, we designed a computational method by combining ligand based pharmacophore modeling and molecular docking for screening the potential natural compounds as EGFR inhibitors. Validation result of ligand based pharmacophore modeling and docking molecular by ROC curves showed that both of these protocols had AUC $\geq 0.7$. The Redocking erlotinib to EGFR in our docking protocols gave the RMSD $<2 \AA$. Therefore, our computational method could be applied for virtual screening. Initial screening based on pharmacophore modeling obtained 86 out of 179.816 compounds that could be mapped with the pharmacophore features. Further screening through molecular docking showed two compounds had a lower docking score than erlotinib, i.e ZINC00941342 and ZINC72325782. However, by careful analysis of their interaction profiles, only ZINC00941342 which formed hydrogen bonds with Met769, which is known as an EGFR key residue. Additionally, it was also found to form hydrogen with Cys773. Therefore, we recommend ZINC00941342 as a potential EGFR inhibitor.
\end{abstract}

\section{Pendahuluan}

Kanker merupakan penyakit global yang menjadi penyebab utama morbiditas dan mortalitas di seluruh dunia (Nurcahyanti, 2016). Saat ini terapi kanker umumnya melibatkan tindakan pembedahan dan radiasi yang biasanya diikuti dengan kemoterapi sistemik menggunakan zat sitotoksik (Rayan et al, 2017). Dalam penggunaannya, zat sitotoksik bekerja tidak selektif sehingga sering menimbulkan efek samping. Oleh karena itu, hingga saat ini terus dikembangkan jenis terapi bertarget dengan selektivitas yang lebih baik dibandingkan kemoterapi sitotoksik (Bagnyukova et al, 2010). Terapi bertarget bekerja dengan memblok penyebaran dan pertumbuhan sel kanker dengan mempengaruhi molekul spesifik atau jalur penting yang terlibat dalam pertumbuhan dan perkembangan sel kanker (Carrington, 2015), salah satunya adalah jalur tansduksi sinyal intraseluler yang dimediasi oleh kelompok enzim tirosin kinase (Bagnyukova et al, 2010). Epidermal growth factor receptor (EGFR) merupakan sub kelompok reseptor tirosin kinase yang sering dioverekspresikan pada beberapa jenis kanker (Harari, 2004). Penghambatan aktivitas
EGFR merupakan salah satu strategi rasional dalam terapi antikanker (Seshacharyulu et al, 2012). Inhibitor tirosin kinase EGFR generasi pertama yang telah disetujui oleh FDA adalah gefitinib dan erlotinib. Obat ini merupakan kelompok small molecule tyrosine kinase inhibitor (TKI) yang bekerja sebagai antagonis ATP di daerah intraseluler (Yewale et al, 2013). Dalam penggunaannya, inhibitor-inhibitor ini memiliki keterbatasan terkait dengan masalah resistensi atau berkurangnya respon tumor. Oleh karena itu upaya mengembangkan inhibitor baru dengan peningkatan efikasi merupakan hal yang sangat penting untuk mengatasi masalah tersebut (Huang \& Fu, 2015).

Dalam upaya penemuan dan pengembangan obat baru, senyawa bahan alam dengan keragaman kimia dan aktivitas biologinya dapat menjadi sumber obat yang baik dan telah menjadi fokus banyak penelitian karena dinilai jauh lebih aman ditinjau dari tingkat toksisitasnya (Yuan et al, 2016). Mempertimbangkan akan adanya kebutuhan inhibitor tirosin kinase EGFR yang lebih poten dengan tingkat keamanan yang lebih baik, maka dalam peneltian ini akan dilakukan skrining 
terhadap suatu database senyawa bahan alam untuk mengidentifikasi inhibitor tirosin kinase EGFR dengan pendekatan Computer-Aided Drug Design (CADD). Pendekatan ini dinilai efisien karena dapat menghemat waktu dan biaya (Sliwoski et al, 2013). Penelitian ini merupakan penelitian eksperimental secara komputasi dan merupakan tahapan awal dalam proses penemuan dan pengembangan inhibitor tirosin kinase EGFR baru dari bahan alam. Diharapkan dari penelitian ini dapat diperoleh senyawa-senyawa hit, yang pada tahap selanjutnya dapat digunakan sebagai senyawa penuntun untuk mendesain inhibitor-inhibitor baru dengan aktivitas dan tingkat keamanan yang lebih baik.

\section{Metode Penelitian \\ II.1 Pengumpulan Data}

Struktur kristal EGFR dalam bentuk kompleksnya dengan erlotinib diunduh dari RSCB Protein Data Bank dengan kode PDB 1m17(Stamos et al, 2002). Kristal EGFR dipisahkan dari pelarut dan ligan menggunakan UCSF Chimera. Hasil pemisahan disimpan dalam format .mol2. Model farmakofor dibangun menggunakan training set yang terdiri dari 26 senyawa aktif seperti yang dipublikasikan oleh Gupta et al (2011). Database senyawa yang akan diskrining adalah senyawasenyawa bahan alam (natural product) dari ZINC database (Irwin \& Shoichet, 2005) yang diakses melalui ZINCPharmer (Koes \& Camacho, 2012). Untuk keperluan validasi model farmakofor dan fungsi skor DOCK 6.7 (Allen et al, 2015), digunakan database yang terdiri dari inhibitor EGFR dan decoynya yang diunduh dari http://dude.docking.org(Mysinger et al, 2012).

\section{II.2 Pemodelan Farmakofor dan Validasi}

Model farmakofor dibangun menggunakan Ligandscout 4.3 (Wolber \& Langer, 2005). Sebanyak 26 senyawa aktif dibuat struktur 3 dimensinya dan dioptimasi dengan Hyperchem 8.0 (Froimowitz, 1993) menggunakan metode semiempiris (PM3) dan hasilnya dsimpan dalam format .mol2. Sejumlah konformasi untuk setiap senyawa dibangun dengan metode iCon best pada Ligandscout 4.3 menggunakan default setting dan selanjutnya dibentuk model-model farmakofor berdasarkan hasil tumpang tindih konformasi setiap senyawa tersebut. 10 model farmakofor dihasilkan pada tahap ini. Model pertama dipilih sebagai model terbaik dan divalidasi performanya dalam membedakan antara senyawa aktif dan decoy (senyawa inaktif) dengan melakukan skrining terhadap DUDE database yang terdiri dari 830 inhibitor EGFR dan 35.411 decoy. Hasil skrining akan diurutkan berdasarkan fit score, dibuat kurva receiver operating characteristic (ROC), dan dihitung nilai area's under the curve (AUC).

\section{II.3. Protokol Docking dan Validasi}

Protokol docking menggunakan DOCK 6.7 diawali dengan preparasi makromolekul (EGFR) dan ligan terlebih dahulu menggunakan program USCF Chimera. Dalam tahap preparasi, makromolekul dan ligan akan ditambahkan atom hidrogen. Muatan ditambahkan dengan metode AM1-BCC. Hasil preparasi disimpan dalam format .mol2. Selanjutnya disiapkan permukaan enzim menggunakan EGFR tanpa atom hidrogen yang sebelumnya dibuat dengan program DMS bawaan USCF Chimera. Spheres di sekitar permukaan enzim EGFR diatur dengan radius minimum dan maksimum masing-masing 1,4 $\AA$ dan 4,0 A. Spheres yang mewakili sisi aktif enzim EGFR diidentifikasi berdasarkan lokasi ligan natifnya (erlotinib) dengan RMSD 8.0 A dari setiap atomnya. Kotak di sekitar sisi aktif diatur dengan margin $5 \AA$ ke 6 arah pembentuk sisi kotak. Selanjutnya protokol docking ini divalidasi dengan melakukan redocking ligan natif erlotinib pada EGFR. Selanjutnya dihitung nilai root mean square deviation (RMSD) dari pose ligan terbaik hasil redocking tersebut. Untuk menentukan kehandalan DOCK 6.7 dalam membedakan senyawa aktif dan inaktif, database DUDE ditambatkan pada EGFR menggunakan protokol docking yang telah dibuat sebelumnya, kemudian dibuat daftar peringkat berdasarkan nilai skor masing-masing senyawa. Dari nilai skor tersebut juga kembali dibuat kurva receiver operating characteristic (ROC) dan dihitung nilai AUCnya.

\section{II.3. Skrining In Silico}

Skrining in silico diawali dengan mengunggah model farmakofor terpilih ke dalam ZINCPharmer. Beberapa parameter tambahan ZINCPharmer diatur sebagai berikut: Maximum of root mean square deviation (RMSD) from sphere centers $=0,5 \AA$; rotatable bonds cut-off = 10; molecular weight $<500$ Daltons. Selanjutnya ZINC database yang terdiri dari 179.816 senyawa bahan alam dipilih untuk proses skrining menggunakan model farmakfor dan parameter yang telah diatur sebelumnya. Hasil skrining diunduh untuk diskrining lanjut menggunakan protokol docking.

\section{Hasil dan Pembahasan}

Dalam penelitian ini proses skrining diawali dengan pemodelan farmakofor, dengan tujuan untuk memperoleh senyawa-senyawa bahan alam yang memiliki gugus farmakofor penting dalam aktivitas farmakologi sebagai inhibitor EGFR. Untuk maksud tersebut, dibangun sebuah model farmakofor dari 26 senyawa yang diketahui sebagai inhibitor EGFR. Model farmakofor ini divalidasi terlebih dahulu untuk memastikan bahwa model tersebut dapat membedakan antara senyawa yang aktif dan tidak aktif. Seperti yang ditunjukkan pada Gambar 1, model farmakofor terpilih memberikan kurva ROC dengan nilai $\mathrm{AUC}_{100 \%}=$ 
0,78. Suatu model dinilai mampu membedakan antara dua karakter yang berbeda dalam hal ini apakah senyawa itu bersifat aktif atau tidak aktif jika nilai AUC kurva ROC > 0,7 (Hosmer, 2013). Dengan demikian, model farmakofor yang terdiri dari 1 gugus hidrofobik, 3 gugus aromatik, 2 akseptor ikatan hidrogen, dan 1 hidrogen bond donor ini (Gambar 1) dinyatakan valid dan dapat digunakan untuk proses skrining. Dari hasil skrining awal ini diperoleh 86 senyawa yang memenuhi kriteria fitur-fitur farmakofor yang dipersyaratkan dan pada tahap selanjutnya akan diskrining kembali menggunakan molecular docking.

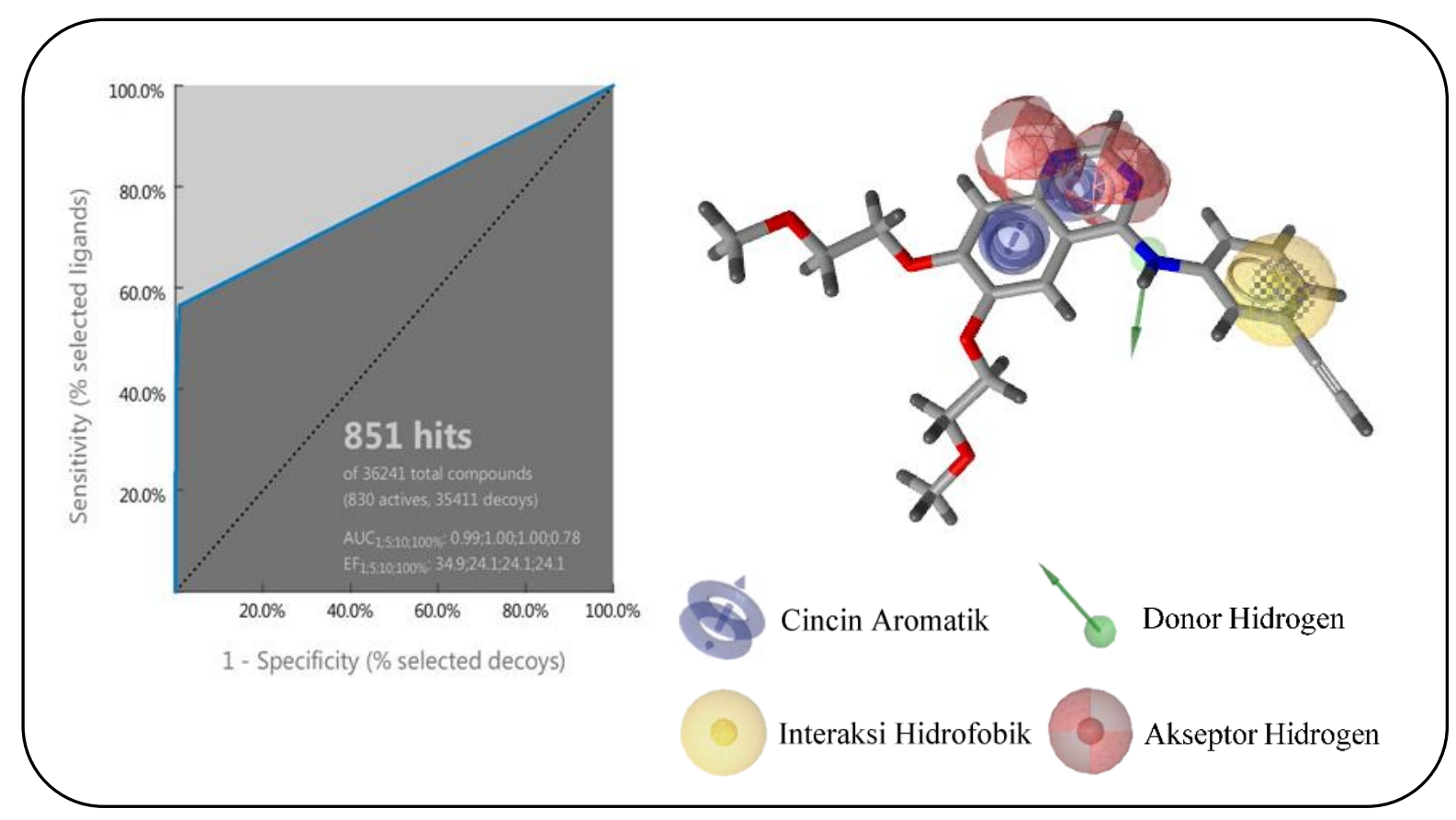

Gambar 1. Kurva ROC protokol skrining berbasis farmakofor dan fitur farmakofor terpilih yang ditumpang tindihkan pada erlotinib

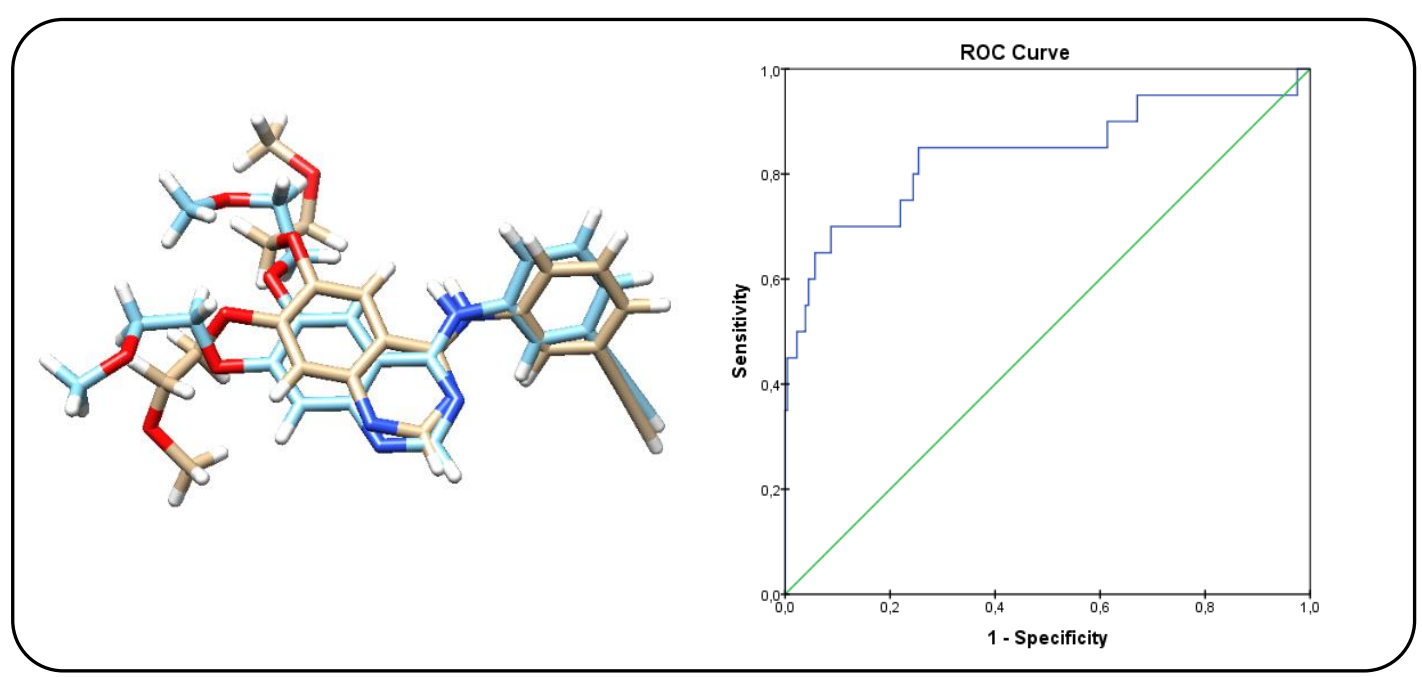

Gambar 2. Pose hasil redocking erlotinib ditumpang tindihkan dengan pose kristalogrfinya dan kurva ROC protokol docking DOCK 6.7 


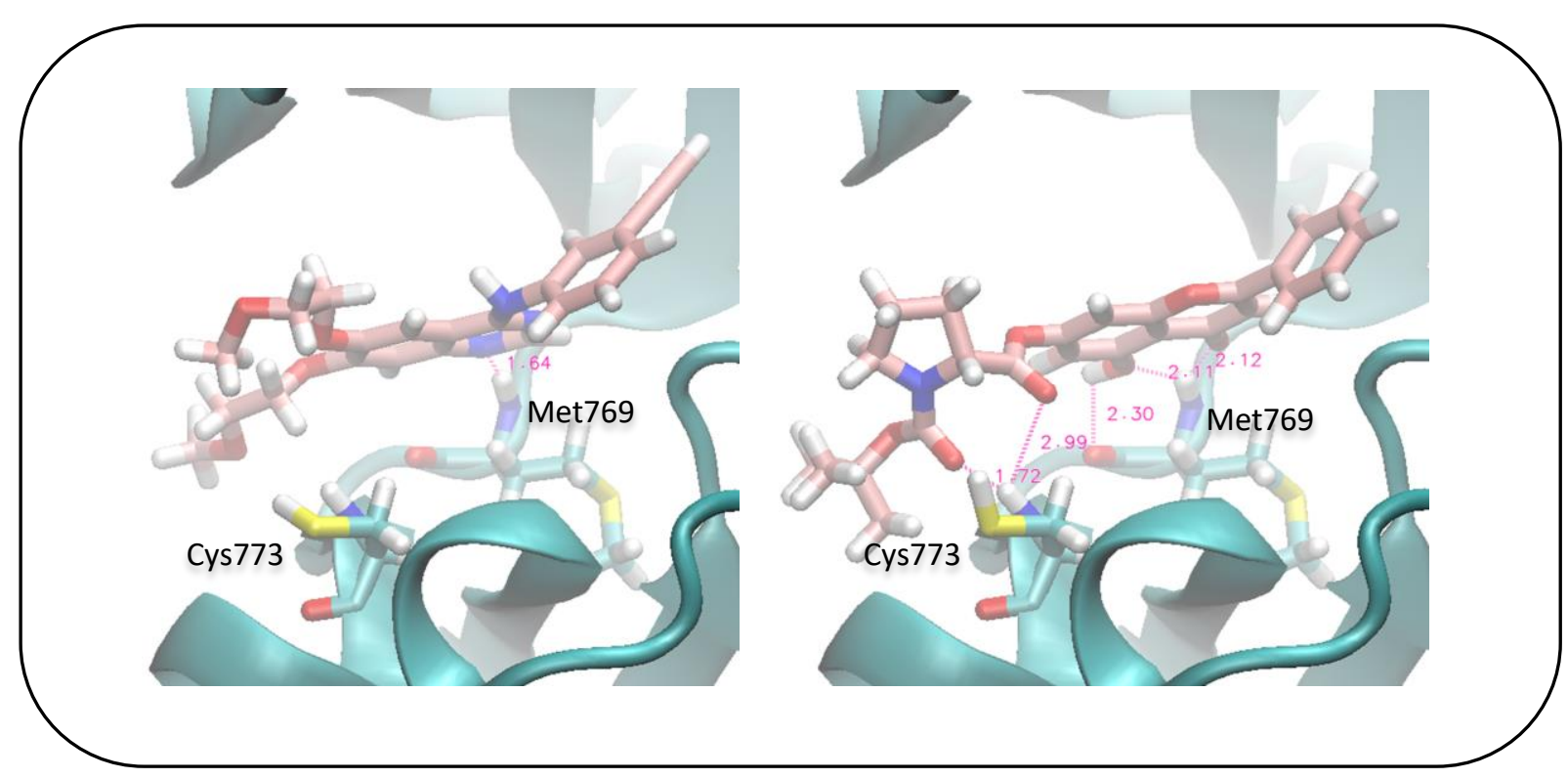

Gambar 3. Profil ikatan hidrogen erlotinib (kiri) dan ZINC00941342 (kanan) dalam kompleksnya dengan EGFR

Untuk skrining berbasis molecular docking, dalam penelitian ini digunakan DOCK 6.7 yang sebelumnya divalidasi terlebih dahulu dengan melakukan redocking erlotinib ke sisi aktif EGFR untuk menjamin keakuratan pose geometrik yang dihasilkan. Selain itu, dilakukan juga vaidasi terhadap fungsi skornya dengan menghitung nilai AUC kurva ROC setelah dilakukan proses docking senyawa-senyawa aktif dan inaktif dari DUDE database pada target EGFR. Pose geometrik hasil redocking dikatakan akurat jika orientasi pose tersebut sesuai dengan pose kristalografinya yang ditunjukkan dengan nilai root mean square deviation (RMSD) kurang dari $2 \AA$ (Hevener et al, 2009). Seperti yang ditampilkan pada Gambar 2, berdasarkan perhitungan RMSD, redocking erlotinib menggunakan DOCK 6.7 diperoleh nilai $\mathrm{RMSD}=1,44 \AA$, sedangkan hasil perhitungan kurva ROC diperoleh nilai AUC $=0,838$. Dengan demikian, protokol docking ini dinyatakan valid dan dapat digunakan untuk proses virtual screening.

Untuk memilih senyawa-senyawa hit pada tahap ini, docking score erlotinib dengan pose terbaik $(-64,26)$ digunakan sebagai nilai batasnya. Berdasarkan hasil skrining terdapat 2 senyawa, yaitu ZINC00941342 dan ZINC72325782 yang memiliki docking score lebih kecil dibandingkan erlotinib. Hal ini megindikasikan bahwa afinitas kedua senyawa terhadap EGFR diprediksi akan lebih baik dibandingkan erlotinib. Dari hasil analisis profil interaksinya (Tabel 1), kedua senyawa berhasil menempati kantung ikatan EGFR dan berintraksi dengan beberapa residu yang sama seperti yang dijumpai pada profil interaksi erlotinib. Akan tetapi, setelah dianalisis lebih lanjut hanya senyawa ZINC00941342 yang membentuk ikatan hidrogen dengan residu Met769 (Gambar 3) seperti yang dijumpai pada profil interaksi erlotinib. Residu ini merupakan residu penting untuk aktivitas penghambatan EGFR (Nasab et al, 2018).

Inhibitor-inhibitor EGFR khususnya turunan 4-aminoquinazolin seperti erlotinib membentuk ikatan hidrogen dengan Met769 melalui atom $\mathrm{N}$ pada cincin quinazolinnya sebagai akseptor hidrogen. Pada desain obat inhibitor EGFR tipe 1 yang bekerja sebagai kompetitor ATP, cincin heterosiklik seperti quinazolin, pirimidin, purin, imidazol, pirazol, oxindol, dan quinolin sering digunakan untuk menggantikan posisi cincin purin dari ATP dan juga berperan sebagai kerangka untuk menempelnya rantai samping yang akan menempati daerah hidrofobik pada daerah katalitik (Zhang et al, 2009). Berdasarkan kerangka strukturnya, ZINC00941342 merupakan golongan senyawa flavon. Senyawa ini memiliki cincin chromen-4-one yang dapat berperan sebagai cincin heterosiklik seperti cincin quinazolin pada erlotinib. Menariknya, struktur cincin ini mampu membentuk 3 ikatan hidrogen dengan residu Met769 dibandingkan erlotinib yang hanya dapat membentuk 1 ikatan hidrogen. Selain itu terdapat juga tambahan ikatan hidrogen dengan residu Cys773 melalui gugus samping pada posisi C7. Berdasarkan studi yang dilakukan oleh $\mathrm{Li}$ et al (2013), adanya tambahan ikatan hidrogen dengan residu Cys773 sangat direkomendasikan dalam upaya mengoptimalkan aktivitas inhibisi ligan ujinya terhadap EGFR. Oleh karena itu ZINC00941342 diprediksi berpotensi besar dalam penghambatan aktivitas EGFR dan direkomendasikan untuk dilakukan pengujian lanjutan pada tahap in vitro untuk membuktikan aktivitas inhibisinya. 
Tabel 1. Stuktur 2D dan profil interaksi erlotinib, ZINC00941342, ZINC72325782 dengan EGFR

\begin{tabular}{|c|c|c|c|c|}
\hline Ligan & Struktu 2D & $\begin{array}{c}\text { Docking } \\
\text { Score }\end{array}$ & Ikatan Hidrogen & $\begin{array}{c}\text { Interaksi } \\
\text { Hidrofobik }\end{array}$ \\
\hline Erlotinib & & -64.26 & Met769 & $\begin{array}{l}\text { Leu694, Ala719, } \\
\text { Lys721, } \\
\text { Leu764, Leu820 }\end{array}$ \\
\hline ZINC00941342 & & -69.15 & Me769, Cys773 & $\begin{array}{l}\text { Leu694, Val702, } \\
\text { Ala719, Lys721, } \\
\text { Leu } 820\end{array}$ \\
\hline ZINC72325782 & & -65.59 & - & $\begin{array}{l}\text { Leu694, Val702, } \\
\text { Ala719, Leu764, } \\
\text { Phe771 }\end{array}$ \\
\hline
\end{tabular}

\section{Kesimpulan}

Berdasarkan kesesuaian fitur farmakofor, docking score dan profil interaksinya dengan EGFR diprediksi senyawa ZINC00941342 mampu menghambat aktivitas proliferasi EGFR. Akan tetapi, masih diperlukan pengujian aktivitas secara in vitro untuk memverifikasi hasil skrining in silico ini.

\section{Ucapan Terima Kasih}

Ucapan terima kasih disampaikan kepada Direktorat Riset dan Pengabdian Masyarakat, Kementrian Riset, Teknologi, dan Pendidikan Tinggi atas dukungannya berupa bantuan dana penelitian.

\section{Daftar Pustaka}

Allen, W.J., Balius, T.E., Mukherjee, S., Brozell, S.R., Moustakas, D.T., Lang, P.T., Case, D.A., Kuntz, I.D., Rizzo, R.C. (2015). DOCK 6: Impact of New Features and Current Docking Performance, Journal of Computational Chemistry, 36(15), 11321156.

Bagnyukova, T., Serebriiskii, Zhou, Y., HopperBorge, E. A., Golemis, E. A., Astsaturov, I. (2010). Chemotherapy and Signaling How can Targeted Therapies Supercharge Cytotoxic Agents?, Cancer Biology \& Therapy, 10(9), 839-853.

Carrington, C. (2015). Oral Targeted Therapy for Cancer, Australian Prescriber, 38(5), 171176.
Froimowitz, M. (1993). Hyperchem: A Software Package for Computational Chemistry and Molecular Modeling, Bio Techniques, 14(6), 1010-1013.

Gupta, A. K., Bhunia, S. S., Balaramnavar, V. M., Saxena, A. K. (2011). Pharmacophore Modelling, Molecular Docking and Virtual Ccreening for EGFR (HER 1) Tyrosine Kinase Inhibitors, $S A R$ and $Q S A R$ in Environmental Research, 22(3), 239-263.

Harari P. (2004). Epidermal Growth Factor Receptor Inhibition Strategies in Oncology, Endocrine-Related Cancer, 11(4), 689708.

Hevener, K.E., Zhao, W., Ball, D.M., Babaoglu, K., Qi, J., White, S.W., Lee, R.E. (2009). Validation of Molecular Docking Programs for Virtual Screening against Dihydropteroate Synthase, Journal of Chemical Information and Modeling, 49(2), 444-460.

Hosmer, D. W., Lemeshow, S., Sturdivant, R. X. (2013). Applied Logistic Regression, 3rd Edition. USA: John Wiley \& Sons.

Huang, L., Fu, L. (2015). Mechanisms of Resistance to EGFR Tyrosine Kinase Inhibitor, Acta Pharmacetica Sinica B, 5(5), 390-401.

Irwin, J. J., Shoichet, B. K. (2005). ZINC - A Free Database of Commercially Available Compounds for Virtual Screening', Journal of Chemical Information and Modeling, 45(1), 177-182.

Koes, D. R., Camacho, C, J. (2012). ZINCPharmer: 
Pharmacophore Search of the ZINC Database, Nucleic Acids Research, 40, 409414.

Li, D-D., Qin, Y-J., Sun, J., Li, J-R., Fang, F., Du, Q-R., Qian, Y., Gong, H-B., Zu, H-L. (2013). Optimization of Substituted 6Salicyl-4-Anilinoquinazoline Derivatives as Dual EGFR/HER2 Tyrosine Kinase Inhibitors, PLoS ONE 8(8), e69427.

Mysinger, M. M., Carchia, M., Irwin, J. J., Shoichet, B. K. (2012). Directory of Useful Decoys, Enhanced (DUD-E): Better Ligands and Decoys for Better Benchmarking', Journal of Medicinal Chemistry, 55(14), 65826594.

Nasab, R. R., Mansourian, M., Hassanzadeh, F., Shahlaei, M. (2018). Exploring the Interaction between Epidermal Growth Factor Receptor Tyrosine Kinase and some of the Synthesized Inhibitors using Combination of In-Silico and In-Vitro Cytotoxicity Methods, Research in Pharmaceutical Science, 13(6), 509-522.

Nurcahyanti, A. (2016). Cervical Cancer: The Case in Indonesia and Natural Product-Based Therapy, Journal of Cancer Biology \& Research, 4(1), 1078.

Rayan, A., Raiyn, J., Falah, M. (2017). Nature is the Best Source of Anticancer Drugs: Indexing Natural Products for Their Anticancer Bioactivity, PloS ONE, 12(11), 1-12.

Seshacharyulu, P., Ponnusamy, M. P., Haridas, D., Jain, M., Ganti, A., Batra, S. K. (2012). Targeting the EGFR Signaling Pathway in Cancer Therapy, Expert Opinion on Therapeutic Targets, 16(1), 15-31.

Sliwoski, G., Kothiwale, S., Meiler, J., Lowe, E. W. (2013). Computational Methods in Drug Discovery, Pharmacological Reviews, 66(1), 334-395.

Stamos, J., Sliwkowski, M.X., Eigenbrot, C. (2002). Structure of the Epidermal Growth Factor Receptor Kinase Domain Alone and in Complex with a 4-anilinoquinazoline Inhibitor, The Journal of Biological Chemistry, 277(48), 46265-46272.

Wolber, G., Langer, T. (2005). LigandScout: 3-D Pharmacophores Derived from ProteinBound Ligands and Their Use as Virtual Screening Filters, Journal of Chemical Information and Modeling, 45(1), 160-169.

Yewale, C., Baradia, D., Vhora, I., Patil, S., Misra, A. (2013). Epidermal Growth Factor Receptor Targeting in Cancer: a Review of Trends and Strategies, Biomaterials, 34(34), 8690-8707.

Yuan, H., Ma, Q., Ye, L., Piao, G. (2016). The Traditional Medicine and Modern
Medicine from Natural Product, Molecules, 21(5), 2-18.

Zhang, J., Yang, P. L., Gray, N. S. (2009). Targeting Cancer with Small Molecule Kinase Inhibitors, Nature Reviews Cancer, 9(1), 28-39. 